\title{
Review Article \\ Hemoglobin Expression in Nonerythroid Cells: Novel or Ubiquitous?
}

\author{
Debarchana Saha, ${ }^{1}$ Mandar Patgaonkar, ${ }^{2}$ Ankit Shroff, ${ }^{1}$ Kanchana Ayyar, ${ }^{1}$ \\ Tahir Bashir, ${ }^{1}$ and K. V. R. Reddy ${ }^{1}$ \\ ${ }^{1}$ Division of Molecular Immunology and Microbiology (MIM), National Institute for Research in Reproductive Health (NIRRH), \\ J.M. Street, Parel, Mumbai 400012, India \\ ${ }^{2}$ Department of Biological Sciences, Tata Institute of Fundamental Research (TIFR), Mumbai 400005, India
}

Correspondence should be addressed to K. V. R. Reddy; reddyk@nirrh.res.in

Received 29 May 2014; Revised 10 October 2014; Accepted 12 October 2014; Published 5 November 2014

Academic Editor: Jean-Marc Cavaillon

Copyright (C) 2014 Debarchana Saha et al. This is an open access article distributed under the Creative Commons Attribution License, which permits unrestricted use, distribution, and reproduction in any medium, provided the original work is properly cited.

Hemoglobin $(\mathrm{Hb})$ is a major protein involved in transport of oxygen $\left(\mathrm{O}_{2}\right)$. Red blood cells $(\mathrm{RBCs})$ contain maximum amount of $\mathrm{Hb}$ and because of their unique structure and plasticity they transport $\mathrm{O}_{2}$ to various tissues of the body at an optimal concentration. Recently, it has been reported that, apart from RBCs, $\mathrm{Hb}$ is also expressed by nonerythroid cells such as epithelial cells of different origin. The cells expressing $\mathrm{Hb}$ are from the tissues where maintenance of $\mathrm{O}_{2}$ homeostasis is of paramount importance. $\mathrm{Hb}$ expression has been observed in the epithelial cells from human tissues including lungs, neurons, retina, and endometrium. Our group has recently demonstrated that $\mathrm{Hb}$ is expressed by the cervicovaginal epithelial cells. We further showed that, apart from maintaining $\mathrm{O}_{2}$ homeostasis, $\mathrm{Hb}$ and the peptides derived from it play an indispensable role in the protection of vaginal epithelium by exhibiting antimicrobial activity. In this review, we discuss the significance of $\mathrm{Hb}$ expression in vaginal epithelial cells and its role in the recognition of pathogens thereby reducing the risk and/or severity of inflammation and/or infections and the possible mechanism by which $\mathrm{Hb}$ exhibits antimicrobial and antioxidative functions.

\section{Introduction}

Hemoglobin $(\mathrm{Hb})$ was accidentally discovered by Hünefeld in 1840 in samples of earthworm blood held under two glass slides. He occasionally found small plate-like crystals in desiccated swine or human blood samples [1, 2]. These crystals were later named as "Haemoglobin" by Hoppe-Seyler in 1864 [3]. Around 1870, Claude Bernard discovered its role as oxygen carrier $[4,5]$. However the discovery of the detailed three-dimensional structure of $\mathrm{Hb}$ by X-ray crystallography is credited to Perutz et al. [6] for which he was awarded the Nobel Prize (1962) in chemistry along with Sir John Kendrew.

$\mathrm{Hb}$ is an iron-containing oxygen-transport metalloprotein found majorly in the red blood cells (RBCs) of all vertebrates [7] except in the fish family Channichthyidae [8] as well as in some invertebrates. The main function of $\mathrm{Hb}$ in mammals is to transport oxygen $\left(\mathrm{O}_{2}\right)$ from the lungs to various tissues of the body, but it is also known to interact with three other gases such as carbon dioxide $\left(\mathrm{CO}_{2}\right)$, carbon monoxide (CO), and nitric oxide (NO).

$\mathrm{Hb}$ is a tetramer made up of two $\alpha$-globin chains and two $\beta$-globin chains which are encoded by two genes located on chromosomes 16 and 11 , respectively. The $\beta$-globin gene cluster is packaged into inactive heterochromatin in nonerythroid cells, whereas the $\mathrm{Hb}-\alpha$ genes are imbedded in open chromatin conformations in all cell types [9]. Each of these chains has a heme moiety attached; thus individual chains can transport oxygen. Under physiological conditions it is involved in transport of oxygen from respiratory organs like lungs to various tissues through red blood cells (RBCs).

The old belief that $\mathrm{Hb}$ and its derived peptides are expressed only by the cells of the erythroid lineage has recently been challenged by many groups who have proved that $\mathrm{Hb}$ expression is much more versatile than previously 
assumed [10]. Recent advances in $\mathrm{Hb}$ research have shown its expression in a wide variety of nonerythroid cells ranging between macrophages [11], alveolar epithelial cells [12, 13], lungs [14], retinal pigment epithelial cells [15], mesangial cells of rat and human [16], hepatocytes [17], neuronal/glial cells [18], endometrial cells [19], and cervical cells [20].

Studies from our laboratory revealed that $\mathrm{Hb}$ is expressed by epithelial cells from cervicovaginal tissue of rabbit [21]. We have also proved that, apart from maintaining the oxygen homeostasis, $\mathrm{Hb}$ and peptides derived from it play an important role in the protection of the vaginal epithelium by exhibiting antimicrobial properties.

1.1. Macrophages. Non erythroid expression of $\mathrm{Hb}$ was first reported in murine macrophages by Liu et al. [11]. On treating with LPS and interferon (IFN-4 $\gamma$ ), they found the activation and expression of only $\mathrm{Hb}-\beta$ minor gene in the stimulated macrophage RAW264.7 cells. The induction of $\beta$ globin was shown from $3.5 \mathrm{hrs}$ posttreatment and it lasted for at least 24 hrs. Globin genes have been known to be activated in cell lines transformed by viruses [22, 23]. The authors thus speculated that maybe the $\mathrm{Hb}$ expression in these macrophages was due to the virus transformation. To rule this out, they repeated their study in peritoneal macrophages collected from BALB/c mice and confirmed the expression of $\mathrm{Hb}-\beta$ minor gene in the stimulated cells. The authors hypothesized that the transcriptional machinery involved in the expression of $\mathrm{Hb}$ in the activated macrophages is different and may involve erythroid-specific transcription activators like erythroid Krüppel-like factor (EKLF) or erythropoiesisinducing transcription factor hypoxia inducible factor 1 (HIF1), which may play a role in the transcription of globin genes in activated macrophages in response to hypoxia- or oxidantrelated stress. They further speculated that $\mathrm{Hb}$ has a different functional role in nonerythroid cells by metabolizing $\mathrm{NO}$ and giving protection against nitrosative stress. However, they did not find any relationship between the $\mathrm{Hb}$ expression and NO decay rate in both stimulated and nonstimulated cells. So they concluded that monomeric globin might function in facilitating oxygen transfer to sites where its extensive use is required or have an alternative enzymatic function or help as $\mathrm{O}_{2} / \mathrm{NO}$ sensor. Though the authors have shown $\mathrm{Hb}$ expression, they have only found $\mathrm{Hb}-\beta$ minor gene and that too only in the stimulated macrophages.

1.2. Alveolar Epithelial Cells. Bhaskaran et al. [13] reported significant expression of $\mathrm{Hb}-\alpha$ and $\mathrm{Hb}-\beta$ genes in type II alveolar epithelial cells (AECs) while characterizing differentially regulated genes in type I AECs and type II AECs using DNA microarray analysis. Type II AECs are in close proximity to the environmental oxygen and hence authors have proposed that $\mathrm{Hb}$ might be involved in sensing the oxygen concentrations, facilitation of oxygen transport across air-blood barrier, and scavenging oxygen/nitrogen to reduce oxidative/nitrosative stress. Newton et al. [12] extended these studies on human alveolar epithelial cells and demonstrated the presence of $\mathrm{Hb}$ subunits in ATII adenocarcinoma cells line (ATII cells), Clara-like adenocarcinoma cells (H441), and mouse alveolar epithelial cells (MLE-15). However, they have not determined the presence of heme prosthetic group in these cells. They propose that individual globin chains might have functional roles in these cells and $\mathrm{Hb}$ might be involved in pathologies associated with respiratory diseases.

Idiopathic pulmonary fibrosis (IPF) and chronic obstructive lung disease (COPD) are the major lung associated pathologies. Ishikawa et al. [14] characterized the proteomes of lung tissues taken from the normal individuals and individuals affected with these two pathologies to identify biomarkers for better prognosis of these diseases. They found that $\mathrm{Hb}$ levels are affected severely in the lung epithelium in patients suffering from IPF; however the levels remained unaffected in individuals with COPD. The reduced $\mathrm{Hb}$ levels in IPF cases were due to modification of thiol group in cysteine residue $\left(\mathrm{C}_{105}\right)$ of $\mathrm{Hb}-\alpha$ monomer. This residue is involved in complex formation between two $\mathrm{Hb}-\alpha$ monomers which is essential for optimal function. The modification of this residue in $\mathrm{Hb}-\alpha$ due to oxidative stress in IPF individuals does not allow the formation of $\mathrm{Hb}$ complexes. The authors have shown presence of $\mathrm{Hb}$ in tetrameric form in bronchoalveolar lavage fluid (BALF) and sputum and have shown that $\mathrm{Hb}$ is secreted into these fluids from lung tissues.

Recently Grek et al. [24] have shown enhanced Hb- $\alpha$ and $\mathrm{Hb}-\beta$ expression in ATII cells and MLE-15 cells after induction with hypoxia, where they have clearly determined the relation between oxidative stress and $\mathrm{Hb}$ expression. In this study, authors have reported that regulation of $\mathrm{Hb}$ synthesis in the ATII cells occurs in similar fashion as it takes place in erythroid precursor cells. However, alveolar macrophages did not show expression of any of the genes involved in hematopoietic development. They have determined that hypoxia inducible factors (HIFs) play essential role in $\mathrm{Hb}$ expression in these cells. In this study these authors have proved that the transcription factor GATA-1 is required for expression of $\mathrm{Hb}$ genes in ATII cells. Long term knockdown of GATA-1 with shRNA construct showed up to $70 \%$ reduction in $\mathrm{Hb}$ expression at both transcript and protein levels. The authors conclude that HIFs play crucial role in maintaining the homeostasis in lungs where fluctuations in $\mathrm{O}_{2}$ concentrations may lead to detrimental effects.

1.3. Retinal Pigment Epithelial Cells. Retinal epithelial cells, especially photoreceptors, require high amounts of oxygen which is supplied by choroidal circulation via diffusion [25]. Tezel et al. [15] were intrigued about the proper functioning of the photoreceptors in cases of systemic hypoxia, where inner retinal neurons failed to work normally. They studied the proteome of retinal epithelial cells and showed that its major constituent is $\mathrm{Hb}$ and it compensates their need for excess oxygen. The authors further proved that $\mathrm{Hb}$ is secreted from retinal epithelial cells at the rate of $1.9 \pm 1.2$ attomoles per cell per hour. Electron microscope studies reveal that the secretion of $\mathrm{Hb}$ in vivo is through basolateral membrane. These new findings would be useful to understand the oxygen transport to outer retina and pathogenesis of age related macular degradation. 
1.4. Mesangial Cells. Kidney is very sensitive to the oxygen changes due to oxygen diffusion between arterial and venous blood vessels. In a study to investigate pathogenesis of chronically hypoxic kidneys, Nishi et al. [16] observed increased expression of $\mathrm{Hb}$ in rat kidney cells. The authors found expression of $\mathrm{Hb}$ in the glomerular mesangial cells. The significance of $\mathrm{Hb}$ expression in these cells was determined by in vitro overexpression studies. Primary rat mesangial cells were cultured and stimulated with hydrogen peroxide $\left(\mathrm{H}_{2} \mathrm{O}_{2}\right)$ to induce chronic hypoxia, which resulted in significant increase of $\mathrm{Hb}-\alpha$ and $\mathrm{Hb}-\beta$ transcripts. When these cells were transfected with vectors carrying $\mathrm{Hb}-\alpha$ and $\mathrm{Hb}-\beta$ genes, overexpression of these proteins was observed. These transfected cells were then stimulated with $1000 \mu \mathrm{M} \mathrm{H} \mathrm{H}_{2} \mathrm{O}_{2}$ to analyze if the $\mathrm{Hb}$ expression has antioxidative properties. It was observed that intracellular generation of reactive oxygen species (ROS) was inhibited significantly in the cells expressing excess of $\mathrm{Hb}$ as determined by immunofluorescence studies. Lactate dehydrogenase (LDH) assay showed increase in the viability of $\mathrm{Hb}$ overexpressing cells compared to normal cells in the presence of $1000 \mu \mathrm{M} \mathrm{H}_{2} \mathrm{O}_{2}$.

1.5. Hepatocytes. Liu et al. [17] have studied the pathogenesis of nonalcoholic steatohepatitis (NASH). While analyzing microarray data to identify differentially expressed genes in $\mathrm{NASH}$ they found that free $\mathrm{Hb}-\alpha$ and $\mathrm{Hb}-\beta$ subunits in serum were significantly increased from normal controls to steatosis and to NASH. They hypothesized that oxidative stress upregulates $\mathrm{Hb}$ expression and $\mathrm{Hb}$ overexpression suppresses oxidative stress in HepG2 cells suggesting that maybe $\mathrm{Hb}$ plays a protective role in NASH. They confirmed the expression of $\mathrm{Hb}$ in NASH liver biopsies and HepG2 cells. NASH biopsies showed $\mathrm{Hb}-\alpha \mathrm{l}$ and $\mathrm{Hb}-\beta$ protein expression in the cytoplasm of the hepatocytes and there was a 6.7fold increase and a 7.9-fold increase in the relative copy numbers respectively. In HepG2, $\mathrm{Hb}-\alpha 1$ transcript expression was about 17 -fold higher than $\mathrm{Hb}-\beta$ transcript; however they were unable to detect $\mathrm{Hb}-\beta$ protein in HepG2 cells.

Overexpressing $\mathrm{Hb}-\alpha$ and $\mathrm{Hb}-\beta$ in HepG2 cells and treating them with $\mathrm{H}_{2} \mathrm{O}_{2}$ showed significant reduction of oxidative stress in $\mathrm{H}_{2} \mathrm{O}_{2}$ treated $\mathrm{Hb}$ overexpressing cells, compared to $\mathrm{H}_{2} \mathrm{O}_{2}$ treated control cells. They speculated that increased $\mathrm{Hb}$ in NASH was due to the induction of erythropoiesis. But the absence of significant increase in the expression of erythrocyte specific genes such as delta aminolevulinate synthase 2 (ALAS2), glycophorin A (GYPA), $\alpha$ - and $\beta$-spectrin (SPTA, SPTB), and hematopoietic transcription factor GATA1 raised the possibility of a different mechanism other than erythropoiesis. They suggested that transcription factor, nuclear factor- (erythroid-derived 2-) like $2(\mathrm{Nrf2})$, which is known to be a crucial mediator of oxidative stress, might be involved in the induction of $\mathrm{Hb}$ expression in these cells.

1.6. Neuronal Cells. Biagioli et al. [18] while studying gene expression profiles found the presence of $\alpha$ - and $\beta$-chain transcripts of $\mathrm{Hb}$ in the subpopulation of dopamine (DA) neurons, cortical and hippocampal astrocytes, and all mature oligodendrocytes of mouse brain. Gene expression analysis of MN9D cells stably transfected with $\mathrm{Hb}-\alpha$ and $\mathrm{Hb}-\beta$ showed that $\mathrm{Hb}$ expression acts on the genes responsible for $\mathrm{O}_{2}$ homeostasis. So, they suggested that $\mathrm{Hb}$ may act as an oxygen reservoir for anoxic and hypoxic conditions and control mitochondrial function. Thus, $\mathrm{Hb}$ may play a key role in the normal physiology of the brain and neurodegenerative diseases.

Russo et al. [26] further extended their study and showed that $\mathrm{Hb}$ is present as $\alpha_{2} \beta_{2}$ tetramer when overexpressed in dopaminergic MN9D cell line. They suggested that neuronal $\mathrm{Hb}$ may retain some of the biochemical activities and biological functions of $\mathrm{Hb}$ of erythroid lineage laying down the foundation for a better understanding of its role in brain physiology and in neurodegenerative diseases. Schelshorn et al. [27] demonstrated $\mathrm{Hb}$ expression in rat and mice neurons. They showed $\mathrm{Hb}$ expression by immunostaining in only the cerebral cortex, hippocampus, striatum, and cerebellum of the mouse brain, but not in astrocytes and oligodendrocytes, which is contradictory to what Biogioli group [18] had reported. Overexpressing $\mathrm{Hb}$ in the E18 cortical neurons cultured from rat brain showed better oxygenation when subjected to hypoxia. They also found that erythropoietin (EPO) induces $\mathrm{Hb}$ expression in these neurons. Therefore, they hypothesized that hypoxia induces production of growth factor EPO which in turn stimulates $\mathrm{Hb}$ expression in the mouse brain and thus $\mathrm{Hb}$ may play a role in improving the oxygen situation. Also, they were the first to report the presence of total $\mathrm{Hb}$ along with its prosthetic group, heme. They showed the presence of heme indirectly by showing an 8.8-fold increase in the expression of ALAS which is a key enzyme in heme synthesis, after EPO injection.

Recently, Richter et al. [28] showed Hb- $\alpha 2$ and $\mathrm{Hb}-\beta$ expression in the nigral, cortical, and striatal neurons from rat brains and striatal neurons in mice. Immunostaining showed presence of $\mathrm{Hb}-\alpha$ chains in the cortex, basal ganglia structures, hippocampus, and hypothalamus and $\mathrm{Hb}-\beta$ chains in cortical and thalamic dendrites, hippocampal cells, and substantia nigra pars reticulata of rat and human brain. Systemic treatment of rats with low doses of rotenone (a mitochondrial toxin) showed downregulation of $\mathrm{Hb}-\alpha 2$ and $\mathrm{Hb}-\beta$ expression in the dopaminergic neurons of the SNC as well as in cortical pyramidal neurons and in GABAergic projection neurons of the striatum. Treatment with rotenone has been shown to result in inhibition of the mitochondrial complex I and elevation of oxidative stress [29]. Heme is known to be a strong activator of globin-chain transcription [30] whose synthesis takes place in the mitochondria. Also, $\mathrm{Hb}$ gene expression in erythroid cells is known to be dependent on the activity of the $\alpha$-subunit of hypoxiainducible factor 1 (HIF-1A) [31]. Thus, they attributed the downregulation of $\mathrm{Hb}$ expression to the reduced production of heme or inactivation of HIF-1A. They also concluded that maybe $\mathrm{Hb}$ plays a protective role against oxidative and nitrosative stress by binding to $\mathrm{NO}$, since $\mathrm{NO}$ is the strongest known ligand of the ferrous heme iron of $\mathrm{Hb}$, with a higher affinity than oxygen. Heme is known to be a strong activator of globin-chain transcription whose synthesis takes place in 
the mitochondria. Also $\mathrm{Hb}$ gene expression in erythroid cells is dependent on the activity of the $\alpha$-subunit of HIF-1A.

1.7. Endometrial Cells. Oxygen homeostasis in endometrium is crucial during earliest stages of embryo development; fluctuations in the oxygen concentrations during 1st trimester may lead to miscarriages by disruptions of villous tissue [32]. Dassen et al. [19] have reported expression of $\mathrm{Hb}$ in endometrial epithelial cells at transcript as well as protein levels. These authors observed in this study that $\mathrm{Hb}$ expression in endometrium is not regulated by hormones. Immunolocalization studies with pan- $\mathrm{Hb}$ antibody revealed that $\mathrm{Hb}$ is expressed by epithelial cells as well as endothelial cells. Stromal cells also showed presence of $\mathrm{Hb}$. In this study, the expression of cytoprotective enzyme, hemeoxygenase-1 (HO1), was observed in the epithelial cells of endometrium. HO-1 is an enzyme that catalyzes degradation of heme moieties to biliverdin, iron, and CO. Heme is synthesized by all nucleated cells and its involvement in the metabolic reactions depends on the protein with which it binds as a prosthetic group. In case of $\mathrm{Hb}$, heme has iron molecule that binds with oxygen molecule and thus transports oxygen in the system. However excess of free heme moieties is toxic to the cells: they carry out various oxidative reactions and protein aggregations and also damage DNA due to oxidations. This toxic response of heme is neutralized by HO-1 [33]. The presence of $\mathrm{Hb}$ and $\mathrm{HO}-$ 1 enzyme in the endometrial tissue signifies the importance of these molecules in the tissue to regulate heme, iron, and oxygen concentrations.

1.8. Cervicovaginal Epithelial Cells. Oxidative stress is caused by an imbalance between the formation of active oxygen metabolites and the rate at which they are scavenged, and it has been associated with the pathogenesis and complications of several diseases, including cancer. The overproduction or inadequate removal of ROS such as $\mathrm{H}_{2} \mathrm{O}_{2}$, hydroxyl radicals, and superoxide anion is associated with cancer [17].

$\mathrm{Li}$ et al. [20] have reported the expression of $\mathrm{Hb}$ in both normal and cancerous human cervical tissue. Immunohistochemistry studies showed diffused cytoplasmic staining. On carrying out microarray, they found increased expression of both $\mathrm{Hb}-\alpha 1$ and $\mathrm{Hb}-\beta$ in the patient tissue sample as compared to the normal. However they did not find any increase in the expression of transcription factors for erythroid differentiation and erythroid cell markers or in the other $\mathrm{Hb}$ genes such as $\mathrm{Hb}-\delta, \mathrm{Hb}-\varepsilon, \mathrm{Hb}-\gamma, \mathrm{Hb}-\theta 1$, and $\mathrm{Hb}-$ $\zeta$. They further confirmed these findings by qRT-PCR and immunostaining. Expression of $\mathrm{Hb}$ was also confirmed in the cancerous cell lines such as $\mathrm{SiHa}$ and CaSki as well as in human embryonic kidney 293 cells (HEK293) by qRTPCR. They found the expression of Hb- $\alpha 1$ to be 9.6 -fold higher than that of $\mathrm{Hb}-\beta \mathrm{Hb}$ expression was also found to be upregulated in the presence of $\mathrm{H}_{2} \mathrm{O}_{2}$ in HEK293, $\mathrm{SiHa}$, and CaSki cell lines. Transient transfection of $\mathrm{SiHa}$ and CaSki cells overexpressing $\mathrm{Hb}-\alpha 1$ and $\mathrm{Hb}-\beta$ showed reduced intracellular ROS and also improved cell viability in the presence of $\mathrm{H}_{2} \mathrm{O}_{2}$. The authors thus hypothesized that $\mathrm{Hb}$ is part of the endogenous antioxidant defense system and protects cells against oxidative damage in cervical cancer patients.

Vaginal inflammation is linked to oxidative stress. Recent studies from our laboratory revealed the expression of $\mathrm{Hb}$ in cervicovaginal epithelial cells in rabbits. In one of the studies, we identified $\mathrm{Hb}$ subunits in the antimicrobial fraction of rabbit vaginal lavage. Further a peptide, RVFHb $\alpha$, was designed from $\mathrm{Hb}-\alpha$ subunit which has shown antimicrobial activity [21]. The peptide showed activity against various pathogenic strains of microbes as well as HIV. The peptide has LPS binding activity and thus neutralizes the inflammatory effects caused by LPS [34]. In order to evaluate the localization of $\mathrm{Hb}$ in cervicovaginal tissue we used antiRVFHb $\alpha$ P antibodies where it was observed that $\mathrm{Hb}-\alpha$ was localized in the glandular epithelial cells. This expression was further confirmed by commercially available antibodies against whole $\mathrm{Hb}$ molecule where similar expression was observed (Figure 1). Preincubated mixture of $\mathrm{Hb}$ antibody and $10 \mu \mathrm{g} \mathrm{Hb}$ was used as a specificity control, where no or negligible localization was observed. In our subsequent studies, three cell lines derived from cervicovaginal tissue of human and immortalized with HPV E6E7 were used [35]. We observed the expression of both subunits Hb$\alpha$ and $\mathrm{Hb}-\beta$ in these cells using commercially available antibodies against these proteins (Figure 2). The expression of $\mathrm{Hb}-\alpha$ and $\mathrm{Hb}-\beta$ was also observed at transcript level using gene specific primers. Currently we are studying this interesting phenomenon in more detail. Our preliminary results indicate that the expression of $\mathrm{Hb}$ increases 2-3-fold when the cells are treated with physiological concentration $(20 \mu \mathrm{M})$ of hydrogen peroxide which is found in human vaginal fluid [36]. The expression also increased on treatment with LPS $(10 \mu \mathrm{g})$.

At some instances spontaneous oxidation of ferrous heme ion $\left(\mathrm{Fe}^{+2}\right)$ to ferric iron $\left(\mathrm{Fe}^{+3}\right)$ occurs after attachment of oxygen leading to generation of superoxide radicals $\left(\mathrm{O}_{2}{ }^{--}\right)$and $\mathrm{H}_{2} \mathrm{O}_{2}$, which exerts oxidative stress to the host. Antioxidative enzymes like catalase and superoxide dismutase produced by RBCs carry out breakdown of superoxide radicals and $\mathrm{H}_{2} \mathrm{O}_{2}$ and also reduce $\mathrm{Fe}^{+3}$ to $\mathrm{Fe}^{+2}$ which can bind again to oxygen atom. Although approximately $1-3 \%$ of total $\mathrm{Hb}$ remains in oxidized form and it is known as methemoglobin (metHb), cell-free $\mathrm{Hb}$ is always in oxidized form due to reaction of $\mathrm{Hb}$ with environmental oxygen. $\mathrm{H}_{2} \mathrm{O}_{2}$ is toxic to the cells and recently it has been shown that $\mathrm{Hb}$ also possesses antioxidative pseudoperoxidase activity. $\mathrm{Hb}$ in the ferrous state reacts with $\mathrm{H}_{2} \mathrm{O}_{2}$ resulting in the formation of oxoferryl $\mathrm{Hb}\left(\mathrm{Hb}-\mathrm{Fe}^{+4}=\mathrm{O}\right)$. This protein-oxygen complex reacts further with $\mathrm{H}_{2} \mathrm{O}_{2}$ and leads to autooxidation of $\mathrm{Hb}$ leading to formation of ferric $\mathrm{Hb}$ or methemoglobin. This reaction leads to extensive cross-linking between the globin chains and oxidation of cysteine residues in $\beta$ globin protein, which further leads to heme degradation [37]. This reaction can neutralize significant amounts of reactive oxygen species and protect cells by the adverse effects of $\mathrm{H}_{2} \mathrm{O}_{2}$. Moreover, heme liberated during these reactions is reduced to biliverdin, iron, and $\mathrm{CO}$, protecting the cells from heme toxicity. 

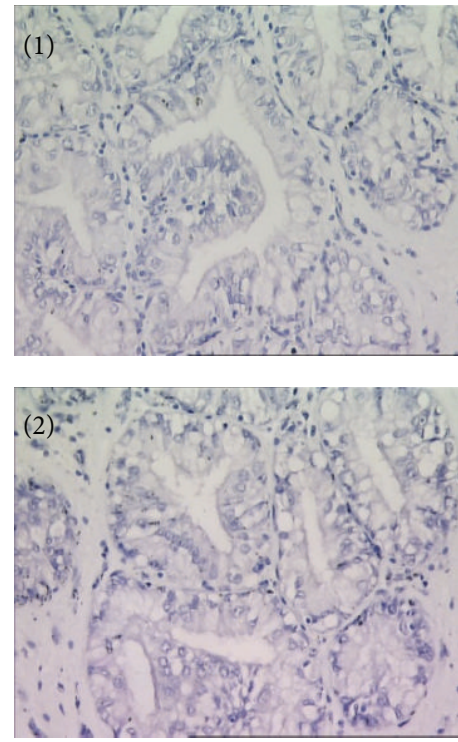

(a)
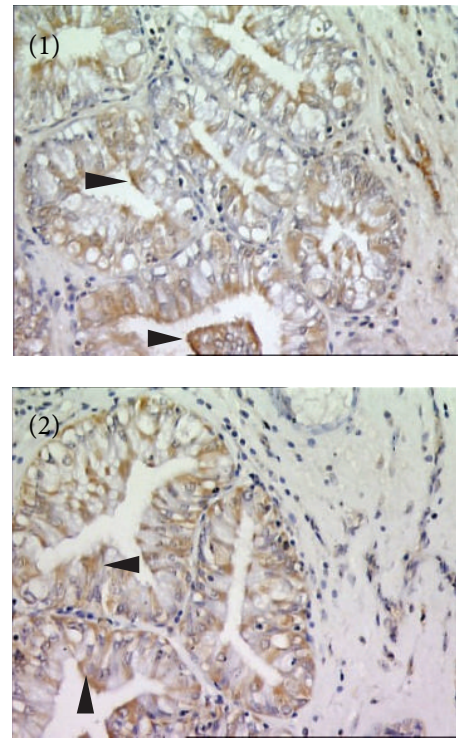

(b)
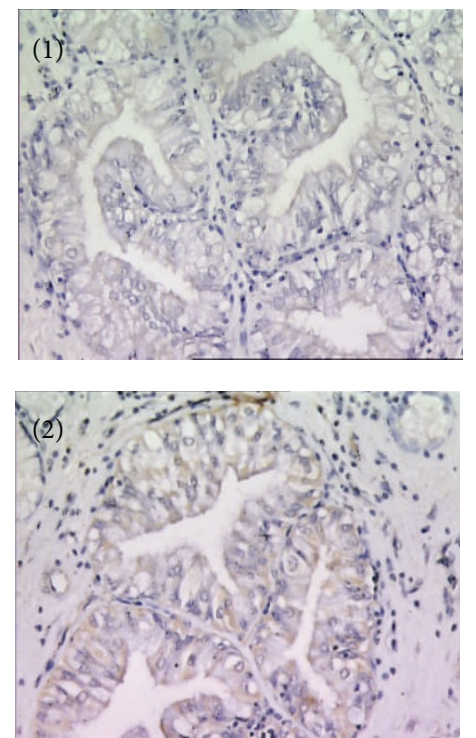

(c)

FIGURE 1: Immunohistochemical localization of RVFHb $\alpha$ P in rabbit vaginal tissue. RVFHb $\alpha$ P localized in glandular epithelium. Upper panel shows RVFHb $\alpha$ P localization and lower panel shows Hb localization. (al) Negative control, (b1) anti-RVFHb $\alpha$ P antibody treated, and (c1) specificity control (10 $\mu \mathrm{g}$ RVFHb $\alpha \mathrm{P}+$ anti-RVFHb $\alpha$ P antibody). (a2) Negative control, (b2) anti-Hb antibody staining, and (c2) specificity control $(10 \mu \mathrm{g} \mathrm{Hb}+$ anti-Hb antibody). Each figure is the representative from three different experiments performed on three different days (magnification $\times 40$; arrow indicates expression of RVFHb $\alpha$ P); Institute Animal Ethics Committee number (IAEC no. 1/2007).

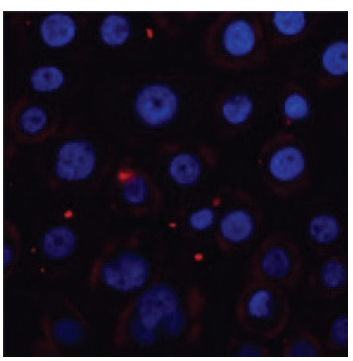

(a)

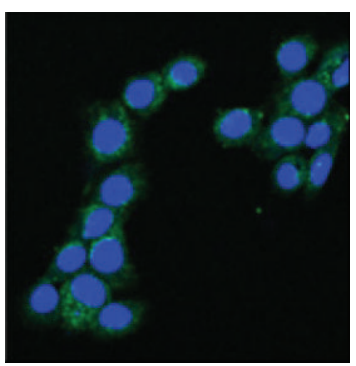

(e)

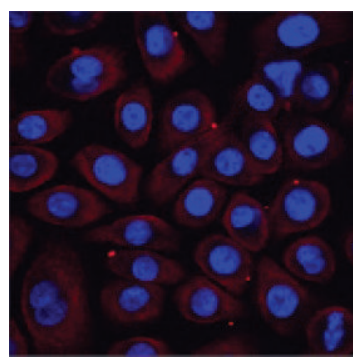

(b)

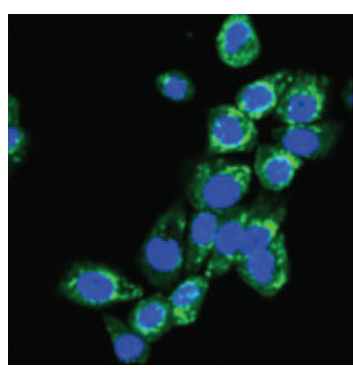

(f)

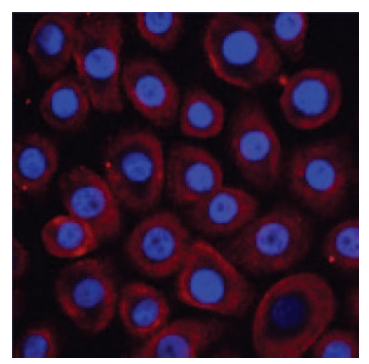

(c)

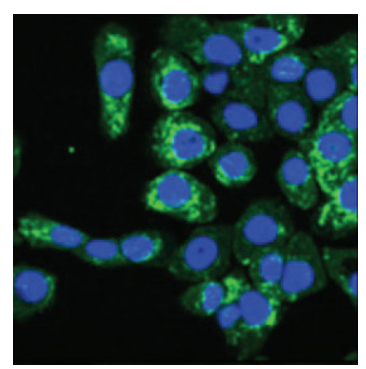

$(\mathrm{g})$

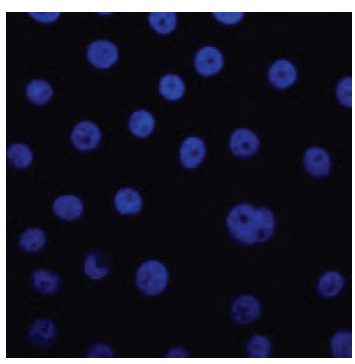

(d)

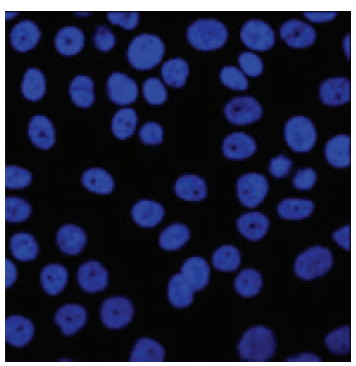

(h)

FIGURE 2: Indirect immunofluorescence localization of $\mathrm{Hb}-\alpha$ and $\mathrm{Hb}-\beta$ subunits in cervicovaginal epithelial cells. The upper panel shows the expression of $\mathrm{Hb}-\alpha$ (red) in VK2/E6E7 cells, control (a), $\mathrm{H}_{2} \mathrm{O}_{2}$ treated (b), LPS treated (c), and negative control (d). The lower panel shows the expression of Hb- $\beta$ (green) in VK2/E6E7 cells, control (e), $\mathrm{H}_{2} \mathrm{O}_{2}$ treated (f), LPS treated (g), and negative control (h). Both subunits were found to be present in the cytoplasm of these cells. Nucleus was stained with DAPI (blue). The figure shown is the representative pictures from three independent experiments (magnification $\times 63$ ). 
Lower female reproductive tract (FRT) functions to protect inner vaginal mucosal epithelial structures from microorganisms. Cellular oxidative stress leading to acute and chronic inflammation contributes to the bacterial and viral infections. Cervicovaginal cells are constantly in contact with $\mathrm{H}_{2} \mathrm{O}_{2}$ secreted by various lactobacilli, inhabiting vagina as commensals. $\mathrm{H}_{2} \mathrm{O}_{2}$ is one of the strong oxidizing agents. $\mathrm{Hb}$, as mentioned earlier, may thus be involved in reducing the oxidative stress caused by various stimuli. Also, at the vaginal mucosal surface, where the host physically interacts with a nonsterile environment, the ability to detect and contain invading pathogens is regularly tested. Escherichia coli which are Gram-negative bacteria are one of the major causative agents for infections in vaginal cells. Gram-negative bacteria are the predominant cause of clinical sepsis. A major constituent of their outer membrane is lipopolysaccharide (LPS) [38], which is a potent stimulator of the immune system. LPS molecules shed from the bacterial surface contribute to the pathology of Gram-negative bacteria sepsis [39]. During Gram-negative sepsis LPS, an endotoxin produced by Gram-negative bacteria, stimulates various proinflammatory cytokines and mediators [40].

As mentioned earlier, $\mathrm{Hb}$ is an LPS binding protein and the structure and biological activity of $\mathrm{Hb}$ are altered in the presence of LPS [41]. LPS can oxidize $\mathrm{Hb}$ and convert metHb, which facilitates iron release and generation of free radicles, a condition known to contribute to $\mathrm{Hb}$ related antibacterial activity. Recently it has also been shown that $\mathrm{Hb}$ can synergize with LPS and LTA during macrophage activation and enhance innate immune responses by inducing expression of cytokines and chemokines [42, 43]. We hypothesize that the expression of $\mathrm{Hb}$ in these cells increases due to inflammation and might be required to neutralize the cytotoxic effects of $\mathrm{H}_{2} \mathrm{O}_{2}$ and LPS. Our preliminary observations support this hypothesis and further studies to corroborate these results are ongoing.

\section{Conclusions and Future Directions}

It is known that the expression of the $\mathrm{Hb}-\alpha$ and $\mathrm{Hb}-\beta$ genes is balanced and coordinated. That is, both genes are expressed at comparable levels in erythrocytes and both are reportedly silenced in nonerythroid cells $[9,22,44]$. Then why are the $\mathrm{Hb}$ genes expressed in nonerythroid cells and why is there a difference between the expression level of $\alpha$ and $\beta$ genes? Some studies have reported increase in expression of $\mathrm{Hb}-\alpha$ as compared to $\mathrm{Hb}-\beta[12,19,20]$ while others have shown the expression levels to be similar. In contrast to these studies, Liu et al. [11] have shown an increase in $\mathrm{Hb}-\beta$ minor and complete absence of $\mathrm{Hb}-\alpha$ subunit in the stimulated macrophages. Thus, $\mathrm{Hb}$ expression in nonerythrocytes may be cell type specific. It is also observed that $\mathrm{Hb}$ expression in nonerythrocytes varies under different conditions. For example, hemoglobin expression was observed to be upregulated in response to oxidative stress and is believed to alleviate it [16, $17,20]$. However, the molecular mechanism of this pathway is poorly understood. It is established that erythroid Hb plays an important role in oxygen transfer and transport. Similarly, in some nonerythroid cells, $\mathrm{Hb}$ expression was found to be upregulated in response to hypoxia $[15,24,26]$. It appears that, to compensate for the increased oxygen demand, $\mathrm{Hb}$ is expressed in these cells. Therefore, expression of $\mathrm{Hb}$ genes in nonerythroid cells under de novo and specific conditions needs to be investigated in detail.

It is known that cell-free $\mathrm{Hb}$ is cytotoxic in nature. Cellfree $\mathrm{Hb}$ molecules have intrinsic toxicity to tissues since harmful ROS is produced during autoxidation of oxyHb to metHb [45]. Then why is $\mathrm{Hb}$ produced in the nonerythroid cells if it is harmful? Maybe the amount of $\mathrm{Hb}$ produced in these nonerythrocytes is way below the amount present in RBCs and, thus, inefficient to cause cytotoxicity to the host cells.

As noted above, expression of $\mathrm{Hb}-\alpha$ and $\mathrm{Hb}-\beta$ is not comparable in nonerythrocytes. To understand this disparity, various studies have analyzed the transcription factors involved in regulating the expression of these genes in nonerythrocytes. GATA-1 is an important transcription factor; it plays a major role in switching fetal hemoglobin to adult hemoglobin during erythropoiesis. Some studies have shown its expression in cells such as neural, alveolar, cervical, hepatocytes $[17,18,20,24]$, while Richter et al. have demonstrated its absence in neural cells [28]. Apart from GATA-1, transcription factors like NFE2, KLF1/EKLF, Hif1$\alpha$, and so forth are expressed de novo or after stimulation. This raises the question whether there are different regulatory mechanisms acting in different cell types. Hence, it is important to study the interplay of various transcription factors depending upon their specific functions in different nonerythroid cells. It would also be interesting to understand whether $\mathrm{Hb}$ expression is regulated by environmental stress and if its regulation is mediated by different transcription factors depending on the external stimuli.

While showing the expression of $\mathrm{Hb}$ at protein and transcript level, most authors have shown the presence of only the globin chains and not the prosthetic group, heme and/or complete $\mathrm{Hb}$ tetramer. An attempt in this direction was made by Schelshorn et al. [27]. They have shown the presence of heme through an indirect observation: increased transcription of ALAS, a key enzyme in heme synthesis. However, this may not necessarily mean that Heme is associated with globin chains since heme is synthesized in all human nucleated cells [46] (it is a component of myoglobin, cytochrome, catalase, etc.). Since it is now known that the expression of both the globins is not comparable in nonerythrocytes, $\mathrm{Hb}$ or its constituents may have different functional significance wherein only the globin monomers, not the entire $\mathrm{Hb}$ tetramer, are required. Further studies to elucidate the complete structure of $\mathrm{Hb}$ expressed in nonerythroid cells and whether it varies from the $\mathrm{Hb}$ found in the erythroid cells need further confirmation.

Till date, $\mathrm{Hb}$ expression has been found in different cells ranging from macrophages to alveolar, lungs, hepatocytes, mesangial, retinocytes, endometrium, cervix, vaginal, and neuronal cells. Maybe with further research we will see that $\mathrm{Hb}$ has more unique functions and is ubiquitously expressed 
in various other cell types of our body. Hence, further studies are required to elucidate the exact mechanism of $\mathrm{Hb}$ expression and its functions in nonerythroid cells.

\section{Conflict of Interests}

The authors declare that there is no conflict of interests regarding the publication of this paper.

\section{Acknowledgments}

The authors are thankful to the Director, National Institute for Research in Reproductive Health (NIRRH), for encouragement to take up studies in the area of immunology and microbiology. The authors acknowledge NIRRH for providing necessary support (NIRRH/REV/147/05-2014). Debarchana Saha and Ankit Shroff are grateful to the University Grant Commission (UGC), New Delhi, for providing Junior Research Fellowships (JRF). Kanchana Ayyar is thankful to Lady Tata Memorial Trust (LTMT) for providing Junior Research Fellowships (JRF).

\section{References}

[1] F. L. Hünefeld, Der Chemismus in der thierischen Organisation, Brockhaus, Leipzig, Germany, 1840, http://www.worldcat.org/title/chemismus-in-der-thierischen-organisation-physiologisch-chemische-untersuchungen-der-materiellen-veranderungen-oder-des-bildungslebens-im-thierischen-organismusinsbesondere-des-blutbildungsprocesses-der-natur-der-blutkorperchen-und-ihrer-kernchen-ein-beitrag-zur-physiologieund-heilmittellehre/oclc/489105995.

[2] R. Giegé, "A historical perspective on protein crystallization from 1840 to the present day," The FEBS Journal, vol. 280, no. 24, pp. 6456-6497, 2013.

[3] F. Hoppe-Seyler, "Ueber die chemischen und optischen Eigenschaften des Blutfarbstoffs," Archiv für pathologische Anatomie und Physiologie und für klinische Medicin, vol. 29, no. 5-6, pp. 597-600, 1926.

[4] C. Bernard, Lecons sur les Effets des Substances Toxiques et Médicamenteuses, Bailliere, Paris, France, 1857, https://archive .org/details/leonssurlesef00bern.

[5] I. Blumenthal, "Carbon monoxide poisoning," Journal of the Royal Society of Medicine, vol. 94, pp. 270-272, 2001, http:// www.ncbi.nlm.nih.gov/pmc/articles/PMC1281520/pdf/0940270 .pdf.

[6] M. F. Perutz, M. G. Rossmann, A. F. Cullis, H. Muirhead, G. Will, and A. C. T. North, "Structure of Hæmoglobin: a threedimensional fourier synthesis at 5.5- $\AA$. Resolution, obtained by X-ray analysis," Nature, vol. 185, no. 4711, pp. 416-422, 1960.

[7] M. Anthea, J. Hopkins, C. W. McLaughlin et al., Human Biology and Health, Prentice Hall, Englewood Cliffs, NJ, USA, 1993, https://www.worldcat.org/title/human-biology-and-health/ oclc/32308337.

[8] B. D. Sidell and K. M. O’Brien, "When bad things happen to good fish: the loss of hemoglobin and myoglobin expression in Antarctic icefishes," The Journal of Experimental Biology, vol. 209, part 10, pp. 1791-1802, 2006.
[9] R. Hardison, "Hemoglobins from bacteria to man: evolution of different patterns of gene expression," The Journal of Experimental Biology, vol. 201, no. 8, pp. 1099-1117, 1998.

[10] R. Du, I. Winarsih, B. Ho, and L. J. Ding, "Lipid-free apolipoprotein A-I exerts an antioxidative role against cell-free hemoglobin," The American Journal of Clinical and Experimental Immunology, vol. 1, no. 1, pp. 33-48, 2012, http://www.ncbi .nlm.nih.gov/pubmed/?term=Lipid-free+apolipoprotein+A-I+ exerts+an+antioxidative+role++against+cell-free+hemoglobin.

[11] L. Liu, M. Zeng, and J. S. Stamler, "Hemoglobin induction in mouse macrophages," Proceedings of the National Academy of Sciences of the United States of America, vol. 96, no. 12, pp. 66436647, 1999.

[12] D. A. Newton, K. M. K. Rao, R. A. Dluhy, and J. E. Baatz, "Hemoglobin is expressed by alveolar epithelial cells," Journal of Biological Chemistry, vol. 281, no. 9, pp. 5668-5676, 2006.

[13] M. Bhaskaran, H. Chen, Z. Chen, and L. Liu, "Hemoglobin is expressed in alveolar epithelial type II cells," Biochemical and Biophysical Research Communications, vol. 333, no. 4, pp. 13481352, 2005.

[14] N. Ishikawa, S. Ohlmeier, K. Salmenkivi et al., "Hemoglobin $\alpha$ and $\beta$ are ubiquitous in the human lung, decline in idiopathic pulmonary fibrosis but not in COPD," Respiratory Research, vol. 11, article 123, 2010.

[15] T. H. Tezel, L. Geng, E. B. Lato et al., "Synthesis and secretion of hemoglobin by retinal pigment epithelium," Investigative Ophthalmology \& Visual Science, vol. 50, no. 4, pp. 1911-1919, 2009.

[16] H. Nishi, R. Inagi, H. Kato et al., "Hemoglobin is expressed by mesangial cells and reduces oxidant stress," Journal of the American Society of Nephrology, vol. 19, no. 8, pp. 1500-1508, 2008.

[17] W. Liu, S. S. Baker, R. D. Baker, N. J. Nowak, and L. Zhu, "Upregulation of hemoglobin expression by oxidative stress in hepatocytes and its implication in nonalcoholic steatohepatitis," PLoS ONE, vol. 6, no. 9, Article ID e24363, 2011.

[18] M. Biagioli, M. Pinto, D. Cesselli et al., "Unexpected expression of $\alpha$ - and $\beta$-globin in mesencephalic dopaminergic neurons and glial cells," Proceedings of the National Academy of Sciences of the United States of America, vol. 106, no. 36, pp. 15454-15459, 2009.

[19] H. Dassen, R. Kamps, C. Punyadeera et al., "Haemoglobin expression in human endometrium," Human Reproduction, vol. 23, no. 3, pp. 635-641, 2008.

[20] X. Li, Z. Wu, Y. Wang, Q. Mei, X. Fu, and W. Han, "Characterization of adult $\alpha$ - and $\beta$-globin elevated by hydrogen peroxide in cervical cancer cells that play a cytoprotective role against oxidative insults," PLoS ONE, vol. 8, no. 1, Article ID e54342, 2013.

[21] M. Patgaonkar, C. Aranha, G. Bhonde, and K. V. R. Reddy, "Identification and characterization of anti-microbial peptides from rabbit vaginal fluid," Veterinary Immunology and Immunopathology, vol. 139, no. 2-4, pp. 176-186, 2011.

[22] P. Cheung, B. Panning, and J. R. Smiley, "Herpes simplex virus immediate-early proteins ICP0 and ICP4 activate the endogenous human $\alpha$-globin gene in nonerythroid cells," Journal of Virology, vol. 71, no. 3, pp. 1784-1793, 1997.

[23] M. Groudine and H. Weintraub, "Rous sarcoma virus activates embryonic globin genes in chicken fibroblasts," Proceedings of the National Academy of Sciences of the United States of America, vol. 72, no. 11, pp. 4464-4468, 1975.

[24] C. Grek, D. Newton, D. Spyropoulos, and J. Baatz, "Hypoxia upregulates expression of hemoglobin in alveolar epithelial cells," 
The American Journal of Respiratory Cell and Molecular Biology, vol. 44, no. 4, pp. 439-447, 2011.

[25] J. E. Grunwald, T. I. Metelitsina, J. C. DuPont, G.-S. Ying, and M. G. Maguire, "Reduced foveolar choroidal blood flow in eyes with increasing AMD severity," Investigative Ophthalmology and Visual Science, vol. 46, no. 3, pp. 1033-1038, 2005.

[26] R. Russo, S. Zucchelli, M. Codrich, F. Marcuzzi, C. Verde, and S. Gustincich, "Hemoglobin is present as a canonical $\alpha 2 \beta 2$ tetramer in dopaminergic neurons," Biochimica et Biophysica Acta-Proteins and Proteomics, vol. 1834, no. 9, pp. 1939-1943, 2013.

[27] D. W. Schelshorn, A. Schneider, W. Kuschinsky et al., "Expression of hemoglobin in rodent neurons," Journal of Cerebral Blood Flow \& Metabolism, vol. 29, no. 3, pp. 585-595, 2009.

[28] F. Richter, B. H. Meurers, C. Zhu, V. P. Medvedeva, and M.-F. Chesselet, "Neurons express hemoglobin $\alpha$ - and $\beta$-chains in rat and human brains," Journal of Comparative Neurology, vol. 515, no. 5, pp. 538-547, 2009.

[29] T. B. Sherer, R. Betarbet, C. M. Testa, B. B. Seo, and J. R. Richardson, "Mechanism of toxicity in rotenone models of Parkinson's disease," The Journal of Comparative Neurology, vol. 23, no. 34, pp. 10756-10764, 2003.

[30] A. S. Tsiftsoglou, A. I. Tsamadou, and L. C. Papadopoulou, "Heme as key regulator of major mammalian cellular functions: molecular, cellular, and pharmacological aspects," Pharmacology and Therapeutics, vol. 111, no. 2, pp. 327-345, 2006.

[31] G. L. Wang and G. L. Semenza, "General involvement of hypoxia-inducible factor 1 in transcriptional response to hypoxia," Proceedings of the National Academy of Sciences of the United States of America, vol. 90, no. 9, pp. 4304-4308, 1993.

[32] E. Jauniaux, L. Poston, and G. J. Burton, "Placental-related diseases of pregnancy: involvement of oxidative stress and implications in human evolution," Human Reproduction Update, vol. 12, no. 6, pp. 747-755, 2006.

[33] S. Kumar and U. Bandyopadhyay, "Free heme toxicity and its detoxification systems in human," Toxicology Letters, vol. 157, no. 3, pp. 175-188, 2005.

[34] M. S. Patgaonkar, A. Sathe, C. Selvaakumar, and K. V. R. Reddy, "A rabbit vaginal cell-derived antimicrobial peptide, RVFHb $\alpha$ P, blocks lipopolysaccharide-mediated inflammation in human vaginal cells in vitro," Clinical and Vaccine Immunology, vol. 18, no. 10, pp. 1632-1643, 2011.

[35] R. N. Fichorova, J. G. Rheinwald, and D. J. Anderson, "Generation of papillomavirus-immortalized cell lines from normal human ectocervical, endocervical, and vaginal epithelium that maintain expression of tissue-specific differentiation proteins," Biology of Reproduction, vol. 57, no. 4, pp. 847-855, 1997.

[36] D. E. O'Hanlon, T. R. Moench, and R. A. Cone, "In vaginal fluid, bacteria associated with bacterial vaginosis can be suppressed with lactic acid but not hydrogen peroxide," BMC Infectious Diseases, vol. 11, article 200, 2011.

[37] C. C. Widmer, C. P. Pereira, P. Gehrig et al., "Hemoglobin can attenuate hydrogen peroxide-induced oxidative stress by acting as an antioxidative peroxidase," Antioxidants and Redox Signaling, vol. 12, no. 2, pp. 185-198, 2010.

[38] E. T. Rietschel and H. Brade, "Bacterial endotoxins," Scientific American, vol. 267, no. 2, pp. 54-61, 1992.

[39] B. Beutler and E. T. Rietschel, "Innate immune sensing and its roots: the story of endotoxin," Nature Reviews Immunology, vol. 3, no. 2, pp. 169-176, 2003.
[40] G. L. Su, R. D. Klein, A. Aminlari et al., "Kupffer cell activation by lipopolysaccharide in rats: role for lipopolysaccharide binding protein and Toll-like receptor 4," Hepatology, vol. 31, no. 4, pp. 932-936, 2000.

[41] R. Du, B. Ho, and J. L. Ding, "Rapid reprogramming of haemoglobin structure-function exposes multiple dualantimicrobial potencies," The EMBO Journal, vol. 29, no. 3, pp. 632-642, 2009.

[42] K. H. Cox, M. E. Cox, V. Woo-Rasberry, and D. L. Hasty, "Pathways involved in the synergistic activation of macrophages by lipoteichoic acid and hemoglobin," PLoS ONE, vol. 7, no. 10, Article ID e47333, 2012.

[43] J. Howe, M. Hammer, C. Alexander et al., "Biophysical characterization of the interaction of endotoxins with hemoglobins," Medicinal Chemistry, vol. 3, no. 1, pp. 13-20, 2007.

[44] M. H. Baron, "Transcriptional control of globin gene switching during vertebrate development," Biochimica et Biophysica Acta, vol. 1351, no. 1-2, Article ID S0167478196001959, pp. 51-72, 1997.

[45] T. Kawano, R. Pinontoan, H. Hosoya, and S. Muto, "Monoamine-dependent production of reactive oxygen species catalyzed by pseudoperoxidase activity of human hemoglobin," Bioscience, Biotechnology and Biochemistry, vol. 66, no. 6, pp. 1224-1232, 2002.

[46] F. A. D. T. G. Wagener, H.-D. Volk, D. Willis et al., "Different faces of the heme-heme oxygenase system in inflammation," Pharmacological Reviews, vol. 55, no. 3, pp. 551-571, 2003. 


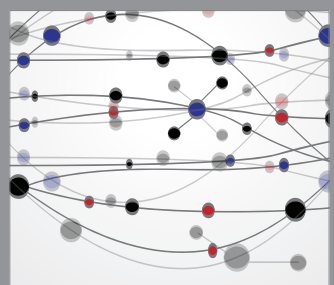

The Scientific World Journal
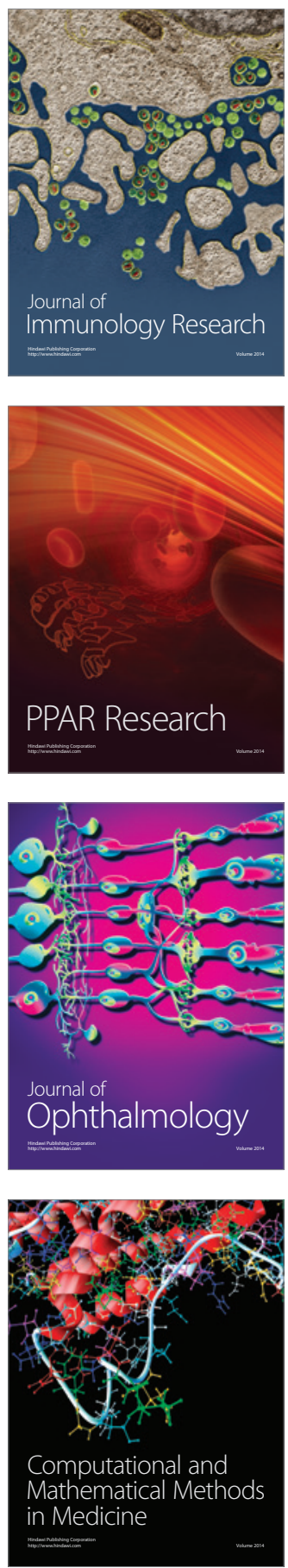

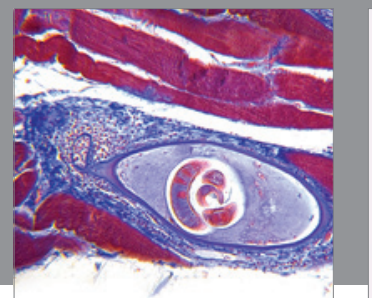

Gastroenterology

Research and Practice
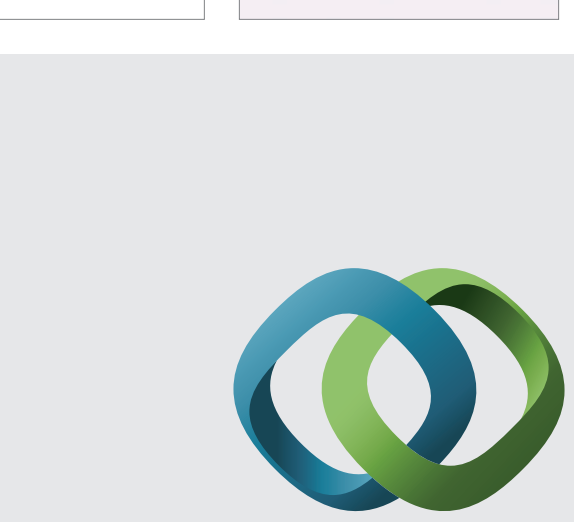

\section{Hindawi}

Submit your manuscripts at

http://www.hindawi.com
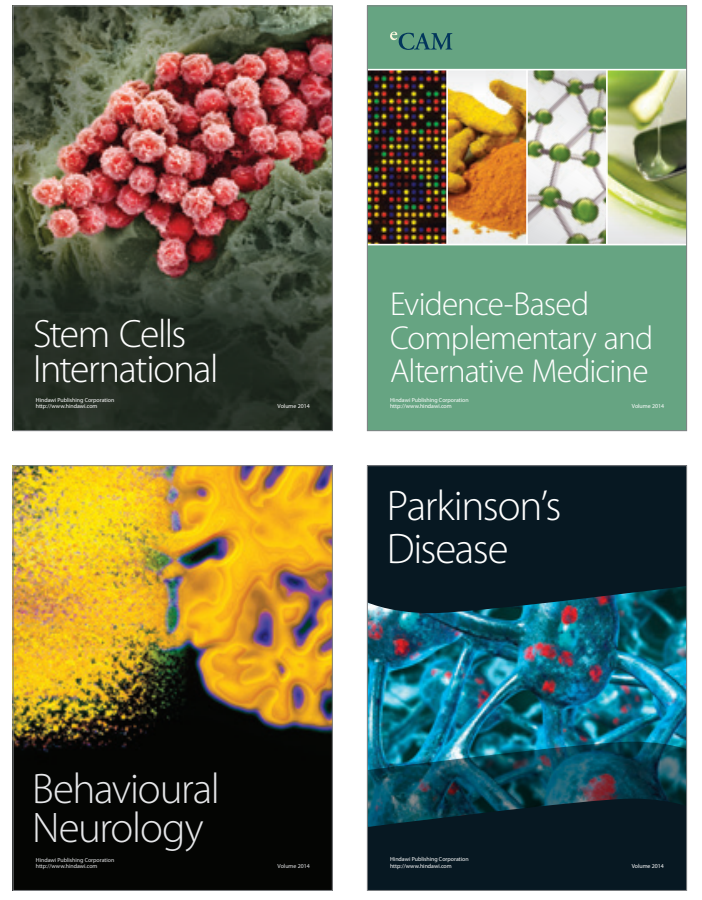
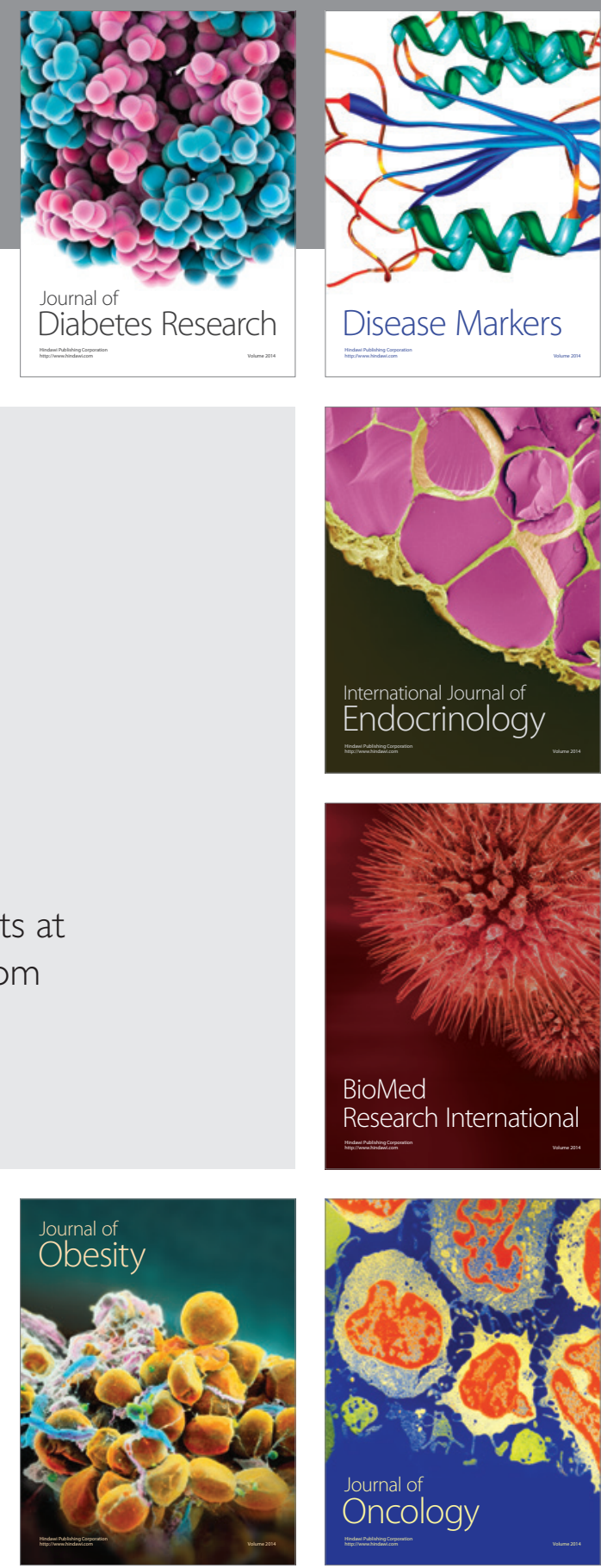

Disease Markers
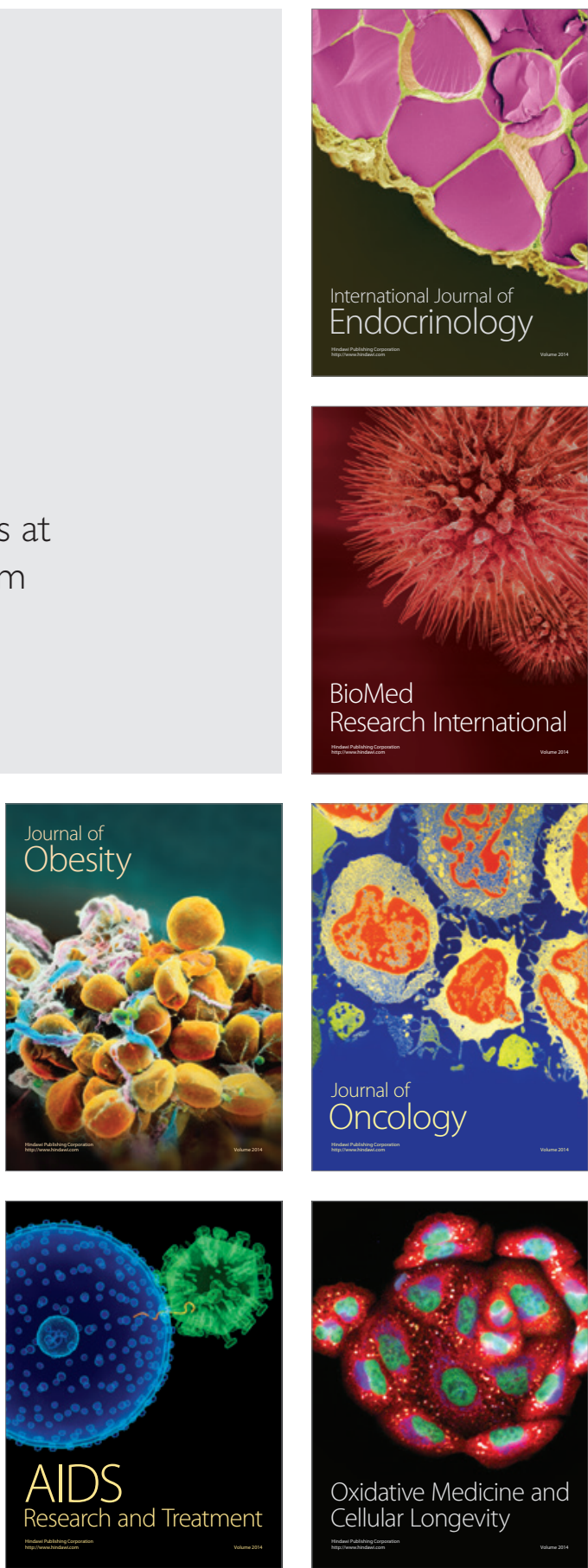